\title{
Sustainable Tourism, a Step Towards India's Economic Growth and Development
}

\author{
Shilpa Anan Mitra \\ M.A B.Ed, SNDT University, Mumbai, Maharashtra
}

\begin{abstract}
It is rightly said that sustainable tourism is important as it generates sustainable local economies. Moreover, sustainable development is a must for any country to achieve Economic development. India is remarkably known for its rich diverse heritage. It is also well-known for all types of tourist destinations at one place. The purpose behind this research study indicates that sustainable tourism not only maintains environmental balance but also boosts the Economic growth and development of a country. The objective of this research shows India's present need of Economic development without hampering the environment. The research work also shows that India, despite being one of the fastest developing economies in the world, is still a developing country and not a developed country yet. India is classified as the world's fifth biggest economy by nominal GDP and the third largest by purchasing power parity. According to the IMF, on a per capita basis, India ranked 142nd by GDP and 119th by GDP per capita in the year 2018 . In spite of all these factors it is seen that the Indian Economy is still lagging behind the developed economies. The paper also provides a theoretical framework on how sustainable tourism helps to create employment opportunities without compromising the socio-cultural and environmental heritage, finally leading India to achieve sustainable development resulting it to enter into a path of developed nation.
\end{abstract}

Keywords: local economies, hampering, socio-cultural, fastest developing economies, theoretical framework.

\section{INTRODUCTION}

Tourism industry in India plays a very significant role for the country's Economic growth and development. In a Developing nation like India, the tourist sector is one of the major sources of income, contributing a large amount to country's GDP. India is blessed with its unique features of biodiversity, rivers, flora and fauna, distinct customs and traditions and its rich culture and heritage and many more. India is also known for its various types of tourisms that is business related tourism, pilgrimage tourism, wildlife tourism, medical tourism, adventure tourism etc. The World Travel and Tourism Council (WTTC) analysis says that tourism sector supported 39.80 million employments which are $8 \%$ of its total employment. Further it is predicted to rise at an annual rate of $6.9 \%$ to $\$ 460$ billion by 2028 which is $9.9 \%$ of GDP. Compare to the top performers in global tourism, India has shown the remarkable improvement by shift from the 40th rank in 2017 to 34th in the Travel and Tourism Competitiveness Report 2019 issued by the World Economic Forum. Henceforth tourism in India is likely to be one of the most income provider sectors. Tourism can be further broadly differentiated between mass tourism and sustainable tourism.

- What is Mass Tourism?

Mass tourism means 'a large number of gatherings of tourists in any particular place, resulting in saturation of the place'. It includes huge gathering of tourists, visitors or voyagers going to a common destination in a regular manner in the meantime of year. The primary goal of mass tourism is making money from the tourism service provider by giving service to as many customers as possible. Basically, it involves mass number of tourists buying standardized commercial products/services leading to less or sometimes no emphasis on sustainability. Some examples of mass tourism are Goa, Shimla, Ooty, Darjeeling etc.

\section{- What is Sustainable Tourism?}

In reverse to that, sustainable tourism focuses on the balance between ecology, economy and socio-cultural aspects. Sustainable tourism basically reduces the costs and increases the benefits of tourism for nature and local communities, and can be carried out without damaging the resources on which it depends. As a result, sustainable tourism creates lesser impact on the environment and local culture and generates income and employment for the local population. The United Nations World Tourism Organization (UNWTO) has announced Year 2017 as the 'International Year of Sustainable Tourism for Development', which emphasize tourism's main role in encouraging inclusive growth. Thenmala in Kerala is one of the examples of sustainable tourism in India. 


\section{International Advanced Research Journal in Science, Engineering and Technology}

Vol. 8, Issue 10, October 2021

DOI: 10.17148/IARJSET.2021.81009

\section{AIMS AND OBJECTIVES OF THE RESEARCH:}

- To know that sustainable tourism brings a positive experience for local communities, tourism industry and the tourists themselves.

- To understand how Sustainable Tourism maintains the balance between ecology, economy and socio- cultural aspects.

- $\quad$ To understand the difference between mass tourism and sustainable tourism.

- To know the benefits and challenges of adoption of sustainable tourism in India.

- $\quad$ To study the impact of Mass tourism on the environment.

- $\quad$ To understand the role of sustainable tourism in a nation's development.

\section{LITERATURE OF REVIEW:}

My research paper entitled Sustainable tourism a step towards India's Economic growth and development is written after I have documented on the basis of the following published articles:

1. "The role of tourism in sustainable economic development" written by Salvo Creaco *University of Catania (Italy) published in conference paper of 43rd Congress of the European Regional Science Association: "Peripheries, Centres, and Spatial Development in the New Europe"

2. "Sustainable Tourism: A State-of-The-Art Review" written by Richard W. Butler and published in the International Journal of Tourism Space, Place and Environment.

\section{RESEARCH METHODOLOGY:}

My research work on "Sustainable Tourism, a Step towards India's Economic Growth and Development" is based on both primary as well as secondary data collection. The primary data collection was carried out by using questionnaire method. A list of questions was prepared for it and it was carried out by using Google form. Approximately 107 respondent samples have been collected. The detail of the same is given in the below table. In secondary data collection, I have collected the information by studying various articles and research papers on this topic and through online sources, journals, newspapers and several websites etc., all the above sources have helped me to complete my research paper.

\section{Data Analysis}

\begin{tabular}{|c|c|c|c|c|}
\hline Sr.no & Questionnaire & Yes & No & \\
\hline 1 & Are you aware of sustainable tourism? & $82.2 \%$ & $17.8 \%$ & \\
\hline 2 & Is India favourable destination for tourism? & $96.3 \%$ & $3.7 \%$ & \\
\hline 3 & $\begin{array}{l}\text { Have you ever visited any Tourists destination } \\
\text { in India? }\end{array}$ & $91.6 \%$ & $8.4 \%$ & \\
\hline 4 & $\begin{array}{l}\text { Have you done any kind of sustainable } \\
\text { tourism within India? }\end{array}$ & $32.7 \%$ & $67.3 \%$ & \\
\hline 5 & $\begin{array}{l}\text { Can sustainable tourism help in country's } \\
\text { development? }\end{array}$ & $96.3 \%$ & $3.7 \%$ & \\
\hline 6 & $\begin{array}{l}\text { Can sustainable tourism lead to increase in } \\
\text { employment opportunities in rural areas? }\end{array}$ & $95.3 \%$ & $4.7 \%$ & \\
\hline Sr.no & Questionnaire & $\begin{array}{l}\text { Sustainable } \\
\text { tourism }\end{array}$ & $\begin{array}{l}\text { Mass } \\
\text { tourism }\end{array}$ & Both \\
\hline 7 & What kind of tourism can you see in India? & $6.5 \%$ & $38.3 \%$ & $\begin{array}{l}55.1 \\
\%\end{array}$ \\
\hline 8 & $\begin{array}{l}\text { Which type of tourism is practice more in } \\
\text { India? }\end{array}$ & $23.4 \%$ & $76.6 \%$ & - \\
\hline 9 & $\begin{array}{l}\text { Which type of tourism leads to environmental } \\
\text { problems? }\end{array}$ & $10.3 \%$ & $89.7 \%$ & - \\
\hline
\end{tabular}

The above table shows the result of data gather by adopting primary data collection. The primary data has been collected by using questionnaire method technique. In this I have collected the response of 107 people. The data helps to analyse the difference between mass tourism and sustainable tourism and also which type of tourism is practice more in India. Further it also demonstrates the outcome of following both mass tourism and sustainable tourism respectively. 


\section{International Advanced Research Journal in Science, Engineering and Technology}

Vol. 8, Issue 10, October 2021

DOI: $10.17148 /$ IARJSET.2021.81009

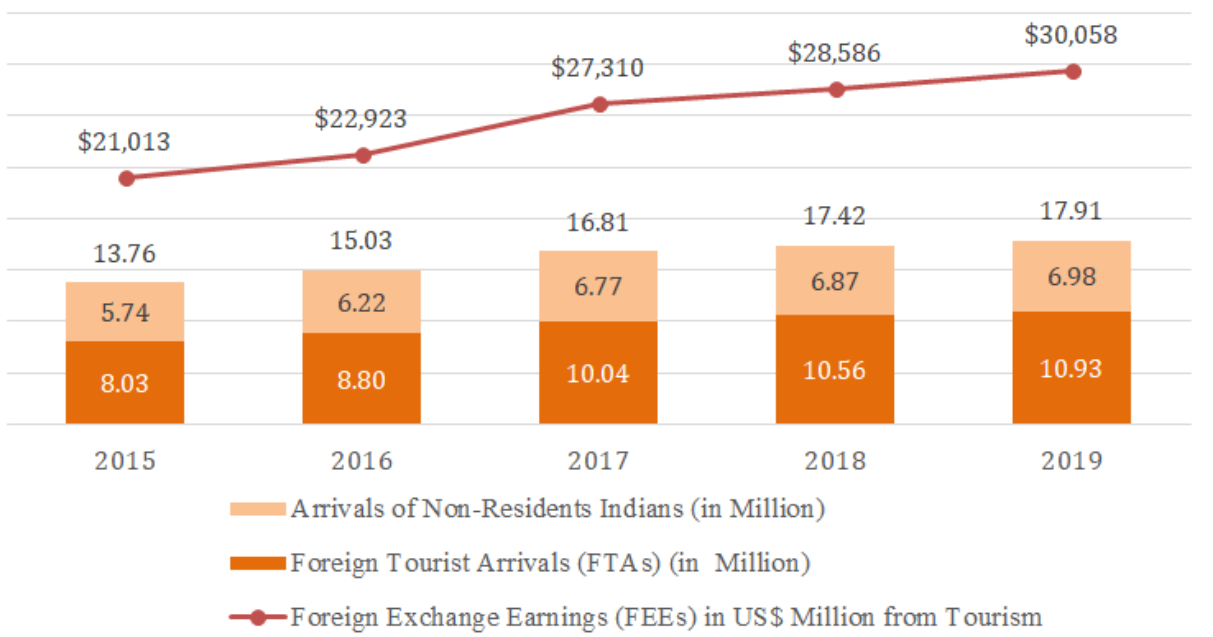

Fig. 1. Important Facts about Tourism in India

Source:

Bureau of Immigration, Govt. of India

Reserve Bank of India, for $2000-2015$

Ministry of Tourism, Govt. of India, for 2016-2019

\section{MAJOR DRAWBACKS OF TOURISM IN INDIA}

Though India's Tourism sector contributes a major share in the country's GDP, but a large part of tourism industry in India practice MASS TOURISM which has some major drawbacks. Mass tourism not only hampers the environment but also restrict the country to gain sustainability. Some of the main reasons are as follows:

- Hamper the local habitat

- Destruction of natural resources

- $\quad$ Rise in pollution

- $\quad$ Exploitation of wildlife by using them for entertainment purposes

- Overcrowding

- Increased burden on local community

- $\quad$ Loss of Amenities for Residents

- Inflation

- $\quad$ Socio-cultural distortions

Though the tourism sector can improve the Economic condition of a particular region, it fails to bring about the complete development of a region without hampering nature. Therefore, the environment, being the most important source of tourism, should be safeguarded for the further rise of tourism as well as economic growth and development in a long run.

\section{BENEFITS OF SUSTAINABLE TOURISM FOR INDIA:}

\section{Environmental benefits:}

Sustainability itself means avoidance of the depletion of natural resources in order to maintain an ecological balance. Sustainable tourism is carried out by creating lesser or no impact on the natural resources. It helps in optimal utilization of available resources. It also helps to reduce environment related problems like pollution, loss of biodiversity, deforestation, global warming, depletion of natural resources and many more. It increases alertness about the needs and issues in our environment.

\section{Economic benefits:}

Sustainable Tourism in India has the potential to promote economic growth and development by creating new jobs related to Tourism. It could be used as a powerful antidote to tackle poverty especially in rural areas. It helps to encourage small local activities. It also helps to raise the standard of living of people. It also helps in marketing new local products and enables the local people to increase their income. 


\title{
International Advanced Research Journal in Science, Engineering and Technology
}

\author{
Vol. 8, Issue 10, October 2021
}

\section{DOI: $10.17148 /$ IARJSET.2021.81009}

\section{Socio-cultural benefits:}

Sustainable Tourism can be carried out without hampering the socio-cultural benefits of a country. It helps to promote the culture of local communities worldwide by bringing together various cultures into contact and this contributes in terms of cultural enrichment. It also helps to preserve the customs and traditions of society. There are many more sociocultural benefits of sustainable tourism, indicating positive impact on society. These includes; preserving the local culture and tradition of the communities, protecting the heritage of a country; building up communities; commercialisation of culture and many more. It also contributes to develop inter-cultural understanding and tolerance.

\section{National benefits:}

Sustainable tourism plays a significant role in nation building. It is essential for every country as it not only protects the environment and natural resources of a country but also improves the quality of life of people both economically and socio-culturally. Sustainable tourism helps a nation in many ways such as to achieve sustainable development goals, to increase the GDP growth rate, to alleviate poverty in rural areas and remote areas, to reduce regional imbalance, helps in rural development, improving infrastructural facilities, helps country to improve its rank in HDI index, increase in standard of living, reduction of global warming and other environmental issues, increase in foreign currency or foreign exchange and many more.

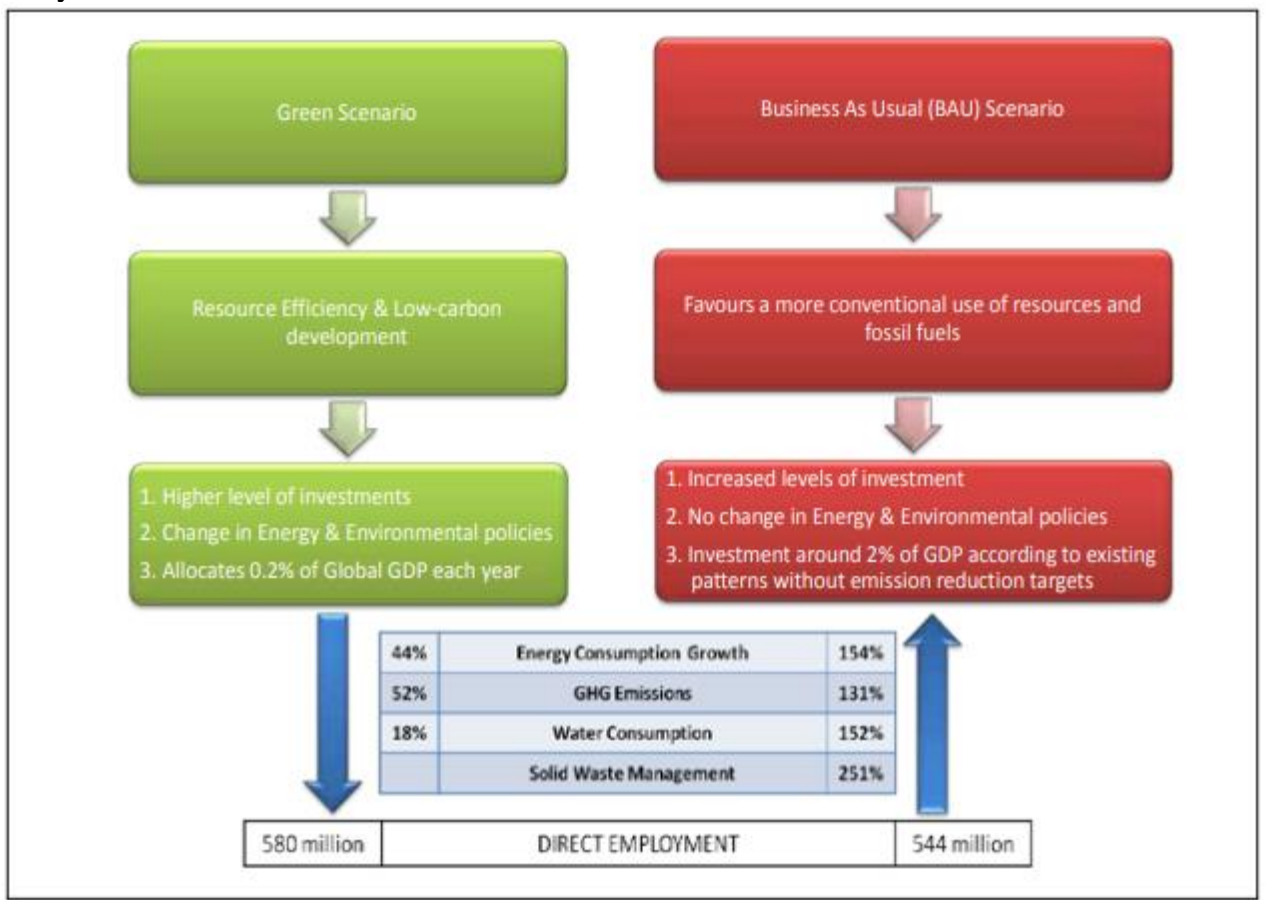

(Source: UNWTO)

Fig. 2. Green Scenario v/s Business as Usual Scenario 2010-2050

\section{CHALLENGES TO PROMOTE SUSTAINABLE TOURISM IN INDIA}

Although sustainable tourism has the potential to suppress the drawbacks of tourism activity without hampering on the economic benefits but it has certain challenges in adoption to sustainable tourism, especially in an emerging tourism sector like India.

- $\quad$ One of the biggest challenges to promote sustainable tourisms is to shift the mind set of domestic tourist industry from practicing mass tourism to sustainable tourism. Moreover, a large portion of the domestic market is still control by mass tourism product.

- The Ministry of Tourism has taken tremendous efforts to prepare Sustainable Tourism Criteria for India (STCI) by adopting the principle of Global Sustainable Tourism Criteria (GSTC) in the Indian context. This will help to guide tourist industry to adopt sustainability in tourism. However, it is observed that the progress is slow due to the need of huge investment involved in adopting such principles.

- Sustainable tourism product can prove to be quite expensive than mass tourism-based product as it involves the higher inputs and localization costs in it. Also, such products are basically nature friendly and handmade goods. As a result, many tourists, especially domestic travellers, are force to settle them for mass tourism product. 


\title{
International Advanced Research Journal in Science, Engineering and Technology
}

\author{
Vol. 8, Issue 10, October 2021
}

\section{DOI: $10.17148 /$ IARJSET.2021.81009}

- $\quad$ To educate large part of people living in rural areas to take up the skills required in tourist activities like hospitality, ethics, basic education for doing small business, training related to tourist guide, motivating them to take new ventures are some other challenges to promote sustainable tourism.

- $\quad$ Continuous assessment on proper implementation of various policies made by Ministry of Tourism related to sustainable tourism is another biggest challenge before Government of India.

- $\quad$ Some of the other challenges before India to encourage sustainable tourism are poor infrastructure facilities, need of cooperation by masses, shortage of well-trained tourist guides, absence of proper organization \& planning, insufficiency of suitable marketing techniques etc.

\section{CONCLUSION}

India has achieved a remarkable position in tourism sector globally. Now it's time for India to attain sustainability in tourism sector. Achieving sustainability in tourists' sector is a continuous and long-term process which requires proper policy framework and proper planning and implementation along with huge investment. Government of India needs to take proper corrective measures from time to time whenever needed. It also requires constant monitoring of the outcomes obtained by the adoption of sustainable tourism in a particular region. India has undergone through economic crises during the time of Covid-19. Tourism sector has suffered a great loss in this pandemic and many people have lost their job. Moreover, India is facing various environmental issues like global warming, destruction of natural resources, loss of biodiversity, depletion of ozone layer etc. Hence sustainable tourism is the need of the time especially for a developing country like India. If India improves its rank in attaining sustainable tourism, then it will help India not only to obtain sustainable development goals but also to enter into a path of Developed Economies. Also, sustainable tourism results in long term Economic benefits without hampering the needs of future generations.

\section{REFERENCES}

1. (2020) India Tourism Statistics at a Glance

2. (June 2, 2021) National Strategy and Roadmap for Sustainable Tourism, Ministry of Tourism Government of India

3. Sustainable tourism in India initiatives \& opportunities - Yes Bank

4. Sustainable tourism for development Guidebook

5. (2019) World Travel and Tourism Council (WTTC) Travel and Tourism Economic Impact Report

6. https://thelogicalindian.com/news/tourism-industry-india-wef-report

7. https://www.financialexpress.com/india-news/five-significant-steps-taken-by-modi-government-to-promote-tourism-hospitality-sector/379469/

8. https://www.ibef.org/industry/indian-tourism-and-hospitality-industry-analysis-presentation

9. http://tourism.gov.in/newsletters

10. https://economictimes.indiatimes.com/news/politics-and-nation/supreme-court-calls-off-wednesday-hearings-as-nationwide-lockdownbegins/articleshow/74821969.cms

11. https://www.incredibleindia.org/

12. Praveen S Kambar (2019), The study of sustainable tourism: with reference to Karnataka state, 'Indian Journal of Research' ISSN: $2250-1991$

13. Monika Singh (2018), Sustainable tourism in Uttarakhand, 'International Journal of the Academic Research and Development' ISSN: $2455-4197$.

14. https://www.niti.gov.in/writereaddata/files/document_publication/Strategy\%20Paper\%20on\%20Resource\%20Efficiency.pdf

15. Jalal K.F. 1990. "Sustainable Development, Environment and Poverty Nexus" Asian Development Bank. 